\title{
COMPADRIO E ESCRAVIDÃO NA BAHIA SEISCENTISTA*
}

Thiago Krause** recebeu um grande impulso, e novas temáticas, fontes e abordagens se multiplicaram. Especialmente prolíficos têm sido os trabalhos que utilizam os registros paroquiais para investigar as relações sociais estabelecidas pelos cativos entre si e com forros, livres pobres e senhores. Entretanto, em sua quase totalidade, as pesquisas têm enfocado os séculos XVIII e XIX, englobando a época que vai da descoberta do ouro no Centro-Sul até o fim da escravidão e o imediato pós-emancipação. ${ }^{1} \mathrm{O}$ século XVII, período formativo da história colonial brasileira, recebeu apenas uma limitada atenção historiográfica, mesmo tendo sido o momento de consolidação da produção açucareira para exportação em

* Este artigo é parte de minha pesquisa de doutorado, financiada por uma bolsa do CNPq. Agradeço às críticas e sugestões de João Fragoso, sem o qual esse artigo não existiria; a Mariana Guglielmo, pelas longas discussões sobre todos os temas aqui tratados; ao parecerista anônimo, pelas correções e sugestões mais que pertinentes; a Ronald Raminelli, Roberto Guedes, Zé Knust, Jonis Freire e Renato Franco, pela leitura atenta e comentários relevantes.

** Professor de História Moderna, Fundação Getúlio Vargas. E-mail: thiagokrause@gmail.com

1 Cf., dentre muitos outros, Stuart Schwartz, "Abrindo a roda da família: compadrio e escravidão em Curitiba e na Bahia", in Stuart B. Schwartz, Escravos, roceiros e rebeldes (Bauru: EDUSC, 2001 [1992]), pp.263-92; Cacilda Machado. A trama das vontades: negros, pardos e brancos na construção da hierarquia social no Brasil escravista. Rio de Janeiro: Apicuri, 2008; João Fragoso, "Efigênia Angola, Francisca Muniz forra parda, seus parceiros e senhores: freguesias rurais do Rio de Janeiro, século XVIII. Uma contribuição metodológica para a história colonial". Topoi, v.11, n.21 (2010), pp.74-106; e Moacir Rodrigo de Castro Maia, "Tecer redes, proteger relações: portugueses e africanos na vivência do compadrio (Minas Gerais, 1720-1750)”. Topoi, v.11, n.20 (2010), pp.36-54. 
grande escala, com a utilização da mão de obra africana nas áreas centrais da América Portuguesa, nomeadamente Bahia e Pernambuco.

Graças ao rico solo do Recôncavo, favorável à produção canavieira, a capitania da Bahia, desde finais do século XVI, era a segunda mais importante no Estado do Brasil, atrás apenas da de Pernambuco. Por volta da terceira década do século XVII, a fase inicial de ocupação do território, com montagem da economia açucareira, transição para a mão de obra escrava africana e formação da primeira elite baiana, já havia sido completada, constituindo-se um grupo dominante com práticas políticas próprias e uma base econômica e social estabelecida. ${ }^{2}$

A invasão neerlandesa de 1630 prejudicou, porém, a produção canavieira de Pernambuco, transformando a Bahia no mais importante centro açucareiro do Brasil e, até a ascensão caribenha na transição para o Setecentos, do mundo. Salvador afirmou-se como um empório comercial de extrema relevância, tendo sua importância se ampliado ao longo do século. Um índice do crescimento baiano é o número de engenhos da capitania, que passou de 84, em 1629, para 146, em finais do século. O comércio que passava pelo porto de Salvador também cresceu ao longo do século XVII, e não só com Lisboa, para onde foram exportadas mais de 7.500 toneladas açúcar em inícios do Setecentos. Mesmo na complicada conjuntura das guerras neerlandesas, entre 1625 e 1650, foram desembarcados mais de 80.000 escravos africanos na capitania, enquanto, no último quartel do século, o tráfico trouxe para as costas baianas mais de 117.000 almas. $^{3} \mathrm{O}$ comércio com a Ásia também cresceu, especialmente a partir de finais do Seiscentos, com a ampliação da importância da Bahia como consumidora e distribuidora dos tecidos indianos. ${ }^{4}$ Salvador

Cf. João Fragoso, “A nobreza da República: notas sobre a formação da elite senhorial do Rio de Janeiro (séculos XVI e XVII)". Topoi, v.1 (2000), pp.45-123 e Rodrigo Ricupero, A formação da elite colonial: Brasil, c. 1530 - c. 1630. São Paulo: Alameda, 2008.

3 Estimativas retiradas de David Eltis, "The Trans-Atlantic Slave Trade Database", <http://www. slavevoyages.org>, acessado em 07/08/2013. Cf. também Jean Baptiste Nardi, O fumo brasileiro no periodo colonial: lavoura, comércio e administração. São Paulo: Brasiliense, 1996, pp.203-21.

4 José Roberto do Amaral Lapa, A Bahia e a Carreira da Índia. São Paulo/Campinas, HUCITEC/ EDUNICAMP, 2000, pp.253-304. Cf. também Roquinaldo Ferreira. “'A arte de furtar': redes de comércio ilegal no mercado ultramarino português (c. 1690-c. 1750)" in João Fragoso e Maria de Fátima Gouvêa (orgs.), Na trama das redes: política e negócios no império português, séculos XVI-XVIII (Rio de Janeiro: Civilização Brasileira, 2010), pp.203-41. 
Tabela 1 - Dados básicos das paróquias analisadas

\begin{tabular}{|c|c|c|c|c|}
\hline & Jaguaripe & $\begin{array}{l}\text { Santo Amaro } \\
\text { da Purificação }\end{array}$ & Paripe & $\begin{array}{c}\text { Santo Amaro } \\
\text { de Itaparica }\end{array}$ \\
\hline Período & $1613-1667$ & $1652-1676$ & $1672-1700$ & $1691-1700$ \\
\hline Número de batismos & $1.706(100 \%)$ & $1.077(100 \%)$ & $738(100 \%)$ & $103(100 \%)$ \\
\hline Inocentes cativos batizados & $824(48 \%)$ & $545(51 \%)$ & $397(54 \%)$ & $29(28 \%)$ \\
\hline Inocentes livres batizados & $874(51 \%)$ & $505(47 \%)$ & $312(42 \%)$ & $56(54 \%)$ \\
\hline Adultos batizados & $8(0,5 \%)$ & $27(2,5 \%)$ & $29(4 \%)$ & $19(18 \%)$ \\
\hline Mães escravas & $594(61 \%)$ & $502(68 \%)$ & $283(67 \%)$ & $27(43 \%)$ \\
\hline Mães livres & $367(38 \%)$ & $230(31 \%)$ & $129(31 \%)$ & $36(57 \%)$ \\
\hline Mães forras/de cor & $13(1 \%)$ & $11(1 \%)$ & $10(2 \%)$ & 0 \\
\hline Engenhos em 1724 & 0 & 39 & 1 & 0 \\
\hline População escrava em 1724 & $1.096(45 \%)$ & $4.152(69 \%)$ & $551(64 \%)$ & $407(57 \%)$ \\
\hline
\end{tabular}

se consolidou, assim, como um importante porto, graças à produção de açúcar e tabaco no Recôncavo e a sua posição estratégica no ultramar português. $^{5}$

Neste artigo, são analisados os dados que podemos extrair a partir das fontes paroquiais baianas seiscentistas, privilegiando três freguesias do Recôncavo: Santo Amaro da Purificação, no quarto de século entre 1652 e 1676; Paripe, no período de 1672 a 1700, e Nossa Senhora da Ajuda de Jaguaripe, de 1613 a 1667. Mencionamos eventualmente Santo Amaro do Catu, na ilha de Itaparica (1691-1700), de características

Cf. Stuart B. Schwartz. Segredos internos: engenhos e escravos na sociedade colonial, 1550-1835. São Paulo: Companhia das Letras, 1988, especialmente pp.77-94; A. J. R. Russell-Wood, "Ports of Colonial Brazil”, in Alain L. Karras e J. R. Mcneill (eds.). Atlantic American Societies: from Columbus to Abolition, 1492-1888 (Nova York: Routledge, 1992), pp.174-211. 
distintas das demais, por ser uma pequena paróquia de pescadores e produtores de alimentos. Em todos os casos, o recorte foi determinado pela sobrevivência dos dados, já que, diferentemente do Rio de Janeiro, a maior parte das fontes eclesiásticas do século XVII se perdeu.

De acordo com um censo eclesiástico de 1724, Santo Amaro possuía 39 engenhos, e $69 \%$ de sua população era escrava, enquanto Paripe dispunha de apenas um engenho e $64 \%$ de escravos. Mesmo que os dados não correspondam à realidade da época englobada pelo recorte aqui feito (Paripe, por exemplo, possuía dois engenhos em 1686), ${ }^{6}$ cremos que a posição relativamente a outras paróquias não deve ter se alterado. Jaguaripe, por sua vez, tinha $45 \%$ de sua população escrava e nenhum engenho, pois já tinha se especializado na produção de alimentos. Entretanto, como havia sido um dos polos de expansão açucareira em finais do século XVI, na primeira metade do Seiscentos ainda possuía alguns poucos engenhos (no mínimo dois, possivelmente quatro). ${ }^{7} \mathrm{Da}$ freguesia de Santo Amaro da Purificação, coração do Recôncavo açucareiro, analisamos um total de 1.077 batismos (outros 309 não podem ser levados em conta, em razão do péssimo estado de conservação da documentação); de Paripe são 738 registros (sendo mais 133 ilegíveis) e de Jaguaripe 1.706 (descartando-se 145 ilegíveis).

A maioria escrava é evidente, pois, em Santo Amaro, 52\% (545) dos batizandos inocentes eram cativos, e 56\% (397) em Paripe, ao passo que, em Jaguaripe, constata-se praticamente uma paridade: 824 eram cativos, e 874 livres (Tabela 1). A taxa de natalidade dos cativos tendia a ser menor que a dos livres, em vista da elevada razão de sexo em uma população majoritariamente africana e das dificuldades cotidianas: essa diferença é especialmente visível quando se compara o número de mães escravas e livres, numa proporção de mais de dois para um, respectivamente, em Santo Amaro e Paripe. Mesmo considerando a imprecisão desse índice, o fato de que a população cativa masculina devia ser maior do que a feminina indica a significativa predominância demográfica dos escravos, provavelmente em níveis similares ou maiores que os do censo de 1724 .

Carta da Câmara de Salvador ao rei D. Pedro II, 20/07/1686, Documentos Históricos do Arquivo Municipal: Cartas do Senado. Salvador: Prefeitura Municipal, 1953, v.III, pp.30-1.

Schwartz, Segredos internos, pp.86-7, 89 e 206. 
Tabela 2 - Mães possuídas por senhor (total de escravas em cada faixa)

\begin{tabular}{|c|c|c|c|c|}
\hline & $\begin{array}{l}\text { Jaguaripe } \\
\text { (1613-1640) }\end{array}$ & $\begin{array}{l}\text { Jaguaripe } \\
\text { (1641-1667) }\end{array}$ & $\begin{array}{c}\text { Santo Amaro } \\
\text { da Purificação } \\
\text { (1652-1676) }\end{array}$ & $\begin{array}{c}\text { Paripe } \\
(1674-1700)\end{array}$ \\
\hline $1-3$ & $98(132)$ & $132(231)$ & $215(387)$ & $127(172)$ \\
\hline $4-6$ & $12(45)$ & $18(80)$ & $22(108)$ & $10(42)$ \\
\hline $7-9$ & $4(31)$ & $6(47)$ & $1(7)$ & $5(38)$ \\
\hline $10-12$ & 0 & 0 & 0 & $1(11)$ \\
\hline $13-15$ & $1(15)$ & $1(13)$ & 0 & 0 \\
\hline $16-18$ & 0 & 0 & 0 & 0 \\
\hline $19-21$ & 0 & 0 & 0 & (20) 1 \\
\hline Total de senhores & (223) 115 & (371) 157 & (502) 238 & (283) 144 \\
\hline
\end{tabular}

Infelizmente, os dados possuem diversas limitações: em Santo Amaro da Purificação, por exemplo, o cura só registrou os batismos realizados na matriz da freguesia, deixando de fora as capelas filiadas, inclusive as situadas nos engenhos, retirando do âmbito de análise os grandes proprietários e seus escravos. Essa ausência explica a extrema desconcentração da propriedade escrava nessa paróquia, coração do Recôncavo açucareiro, como se vê na Tabela 2. O mesmo pode ter acontecido, em algum grau, em Jaguaripe, já que um senhor de engenho como Nicolau Soares batizou apenas cinco cativos entre 1621 e 1650; a vantagem, porém, é que essa é a única freguesia em que os pais dos filhos das escravas são registrados sistematicamente, como veremos abaixo. Em contrapartida, o pároco de Paripe registrava muito menos informações sobre seu rebanho, mencionando pouquíssimas vezes a cor, eventualmente não informando a condição social dos padrinhos ou sequer registrando-os, como fez em $38 \%$ dos batizados de cativos. Chegou a ser admoestado em finais de 1697 pelo visitador Reverendo Cônego Gaspar Marques Vieira, para que "nos assentos dos batizados $\mathrm{p}$ [usesse] os nomes dos padrinhos que não suceda ficarem em branco 
como em alguns desses já feitos" o que, como veremos a seguir, melhorou a qualidade dos registros, aumentando a proporção de padrinhos cativos. Por outro lado, apenas os dados de Jaguaripe cobrem um longo período, de mais de 50 anos, embora a qualidade das informações também por vezes deixe a desejar. Seremos obrigados, assim, a utilizar alternada e comparativamente os dados dessas três paróquias na tentativa de responder às nossas questões.

Como a transição para a mão de obra africana já havia sido completada em meados do Seiscentos, os indígenas eram claramente minoritários, tendo-se registrado apenas dois batizados de gentios da terra, adultos, em Santo Amaro e nenhum em Paripe. Em Jaguaripe, porém, a situação era marcadamente distinta: freguesia que conheceu a famosa Santidade em finais do século XVI, ${ }^{8}$ possuía uma aldeia indígena fundada pelos jesuítas, que a abandonaram em 1613. ${ }^{9}$ Seu intento de movê-los fracassou em razão de uma manifestação dos maiores proprietários da região, requerendo a manutenção da aldeia para garantir a defesa da região (inclusive contra os índios "fugidos" da Santidade), pois, em razão de sua localização geográfica no sul do Recôncavo, representava a "fronteira do sertão", ${ }^{10}$ o que a colocava em contato direto com os índios "bravos" do sertão ainda durante o Seiscentos, ${ }^{11}$ justificando e possibilitando a escravização de indígenas, ${ }^{12}$ identificados alternadamente, nos registros

Ronaldo Vainfas. A heresia dos índios. São Paulo: Companhia das Letras, 1995.

9 Serafim Leite, História da Companhia de Jesus no Brasil, v.5: da Baía ao Nordeste. Rio de Janeiro: Imprensa Nacional, 1945, pp.267-8. Exatamente nesse ano os registros se iniciam, indicando ter sido essa a provável data de instituição da freguesia.

10 "Carta do Rei Felipe II de Portugal ao Governador-Geral do Brasil Gaspar de Sousa, 24/05/1613", in João Paulo Salvado e Susana Münch Miranda (eds.), Cartas para Álvaro de Sousa e Gaspar de Sousa (1540-1627) (Lisboa: CNCDP), 2001, pp.190-2 e "Arrazoado que o Padre Simão Pinheiro, provincial da Companhia de Jesus neste Brasil, apresentou ao senhor governador Dom Luís de Sousa, 25/09/1620" in João Paulo Salvado e Susana Münch Miranda (eds.), Livro $1^{\circ} d o$ Governo do Brasil (1607-1633) (Lisboa: CNCDP, 2001), pp.368-70.

${ }_{11}$ Cf., por exemplo, Governador-Geral Diogo Luiz de Oliveira, Patente ao Capitão-Mor João Rodrigues Adorno, 20/09/1627: Arquivo Histórico Municipal de Salvador (AHMS), Provisões Régias (PR), vol. I, fls. 24v-26, para uma menção a um ataque em 1627. Para uma detalhada análise desses conflitos na década de 1650, cf. Pedro Puntoni, A Guerra dos Bárbaros: povos indígenas e a colonização do sertão nordeste do Brasil, 1650-1720. São Paulo: EDUSP/Hucitec, 2002, pp.89-107.

12 É de se destacar que a lei de 10/09/1611 sobre a liberdade do gentio singularizou Jaguaripe como região onde "se cativaram muitos gentios contra as formas das leis d'El Rei". Cf. Boletim do Conselho Ultramarino: Legislação Antiga. v.1: 1446 a 1754. Lisboa: Imprensa Nacional, 1867, pp.206-11. 
paroquiais, como escravos "da obrigação de" e, principalmente, "sujeitos a" um senhor. ${ }^{13}$

Mesmo nessa paróquia fronteiriça, porém, os "negros da terra" cativos são largamente minoritários, pois encontramos apenas 22 batizados, espalhados entre 1615 e 1657: é de se reconhecer, entretanto, que é muito provável que diversos dos escravos sem identificação sejam antes indígenas que africanos, especialmente nos primeiros anos do período. Os índios livres da aldeia de Santo Antônio eram mais comuns, perfazendo o total de $56-34$ dos quais foram apadrinhados por brancos, indicando uma interação significativa entre os membros da aldeia e a população luso-brasileira de Jaguaripe.

Apesar da predominância da escravidão negra em todas as paróquias, a proporção de africanos variava significativamente, como é possível perceber-se a partir da naturalidade das mães. Em Santo Amaro, mais de $83 \%$ (257) das genitoras cativas cuja origem é mencionada haviam nascido na África: como essa era a freguesia que recebia o maior fluxo dos cativos desembarcados na praça baiana, tal predominância é facilmente compreensível. Já em Jaguaripe, a proporção quase se inverte, pois apenas 35 mães (26\% do total com origem registrada) aparecem como "do gentio da Guiné" ou "Angola”, enquanto 97 (74\%) são crioulas ou mulatas - o que provavelmente significava uma menor predominância masculina entre os cativos, potencializando a formação de laços familiares estáveis, como veremos a seguir.

Falamos brevemente das mães. E os filhos? 312 inocentes cativos de Santo Amaro têm sua cor registrada nos assentos, e o que chama a atenção é o elevado índice de miscigenação, pois 56\% deles são qualificados como mulatos (163) ou mestiços (12), enquanto apenas $44 \%$ recebem a denominação de crioulos (137). Mesmo se considerarmos os outros 233 inocentes que não têm a cor registrada pelo pároco como crioulos (o que é manifestamente falso, pois ao menos três são filhos de livres sem cor declarada, isto é, "brancos", assim como 146 em Jaguaripe), o nível de contato sexual interétnico era muito intenso, o que acabou por gerar

13 Para uma discussão similar sobre a administração dos índios, cf. John Monteiro, Negros da terra: indios e bandeirantes nas origens de São Paulo. São Paulo: Companhia das Letras, 1994, pp.147-53. 
um importante grupo miscigenado no cativeiro - que, como tem sido enfatizado pela historiografia, tinha possibilidades maiores de ocupar posições de confiança, exercer ofícios especializados e obter alforria. ${ }^{14}$

Em Santo Amaro, Itaparica e Paripe, a paternidade dos cativos quase nunca é assumida. Da mesma maneira, dos quatro mulatos nascidos livres, apenas um teve a paternidade declarada. Se o "mulatismo" implicava a inexistência de reconhecimento formal por parte da figura paterna, tal situação não era exclusiva: apenas 45 cativos crioulos ou sem cor (cerca de 6\% do total) têm pais identificados nessas paróquias. Se olharmos para os matrimônios sacramentados na Igreja Católica, o contraste com a população livre fica ainda mais evidente. Nenhum mulato ou pardo, escravo ou livre, foi filho de pais casados, e apenas uma pequena minoria de 30 (3,2\%) escravos em Paripe e Santo Amaro nasceu numa família reconhecida pela Igreja Católica (assim como dois casais de crioulos livres). Isso significa que cerca de 97\% dos escravos eram filhos ilegítimos.

É de se notar que tal índice de ilegitimidade é ainda maior que o encontrado em outras regiões nos séculos XVIII e XIX, como São João Del Rey entre 1736-1850, cuja taxa variou entre 57\% e 89\%; ${ }^{15}$ Campos dos Goitacazes entre 1748-1800, em torno de 53\%; e Jacarepaguá, de $48 \%$ a $62 \%$, entre 1754 e $1804 .^{16}$

Mesmo na Bahia do final do XVIII, o casamento escravo parece ter sido mais frequente que na centúria anterior, pois, nas paróquias e nos anos analisados por Schwartz, a taxa de legitimidade variava entre $10 \%$ e $34 \% .{ }^{17} \mathrm{~A}$ única região com taxas comparáveis foi Vila Rica em 1804, com 98\%, embora não se saiba o quanto esse ano específico é

14 Stuart B. Schwartz, "Alforria na Bahia, 1684-1745” in Stuart B. Schwartz, Escravos, pp.171-218.

15 Silvia Maria Jardim Brügger, Minas patriarcal: família e sociedade (São João Del Rei - séculos XVIII e XIX). São Paulo: Annablume, 2007, pp.76-80 e 115-20.

16 Sheila de Castro Faria, "Cotidiano do negro no Brasil escravista", in José Andrés-Gallego (org.), Tres grandes cuestiones de la historia de Iberoamerica (Madri: Fundación Mapfre Tavera, 2005), pp.54-72; Márcio de Sousa Soares, "Presença africana e arranjos matrimoniais entre os escravos em Campos dos Goitacazes (1790-1831)", História: Questões \& Debates, v.52 (2010), p.88.

17 Schwartz, Segredos internos, p.316-8. A exceção é a freguesia de São Francisco em 1816, onde a taxa de ilegitimidade foi de 100\%. Para Paripe na transição do Oitocentos, cf. Adriana Dantas Reis Alves, "As mulheres negras por cima: o caso de Luzia Jeje. Escravidão, família e mobilidade social - Bahia, c. 1780-c. 1830" (Tese de Doutorado, Universidade Federal Fluminense, 2010), pp.98-150. 
representativo do panorama mais amplo. ${ }^{18} \mathrm{O}$ diferencial em relação à população livre sem cor era muito significativo, pois $86 \%$ dessas crianças em Santo Amaro eram legítimas, assim como 90\% em Paripe e 93\% em Jaguaripe - taxas comparáveis às de diversas paróquias portuguesas, especialmente do Norte (de onde, incidentalmente, vinha a maioria dos imigrantes), e iguais ou maiores do que muitas áreas da América Portuguesa no Setecentos, embora menores do que as encontradas para São Gonçalo seiscentista, no Recôncavo da Guanabara. No reino como nas conquistas, a ilegitimidade entre os livres "sem cor" parece ter sido característica da experiência de mulheres mais pobres, em situação instável e menos inseridas em redes sociais de apoio; ${ }^{19}$ na Bahia seiscentista, por exemplo, as mães solteiras praticamente não aparecem como madrinhas, e quase nunca conseguiam casar e gerar filhos legítimos posteriormente.

Voltemos aos cativos. Jaguaripe distingue-se parcialmente do cenário que traçamos até aqui, pois sua taxa de ilegitimidade entre os cativos foi de "apenas" 79\%: elevada, mas muito menos presente do que em Santo Amaro e Paripe. O que é ainda mais significativo, 80\% dos filhos naturais tiveram pais registrados. A atitude do pároco e seus paroquianos certamente foi um fator preponderante, fosse permitindo o casamento cativo ou, ao menos, aceitando as atribuições de paternidade feitas pelas escravas e seus padrinhos, na característica fórmula "deu-se por pai”, que continuou a ser utilizada até 1667 , quando acabam os registros sobreviventes dessa freguesia. Para deixar mais clara essa oposição, cabe fazer uma rápida comparação: em Santo Amaro, nos 15 anos em que os registros são concomitantes (1652-1667), apenas um francês, Miguel Buqueque, aparece como pai livre de um cativo, em oposição a 76 registrados no mesmo período em Jaguaripe.

Um fator que nos parece importante para a compreensão desse desenvolvimento distinto é o tráfico: como vimos acima, a presença crioula era significativamente maior na freguesia de Jaguaripe, em razão

18 Francisco Vidal Luna e Herbert S. Klein, Escravismo no Brasil, São Paulo: EDUSP/Imprensa Oficial, 2010, pp.248-9.

19 Ana Silvia Scott, "O pecado na margem de lá: a fecundidade ilegítima na metrópole portuguesa (séculos XVII-XIX)”. População \& Família, n.3 (2000), pp.41-70; Brügger, Minas patriarcal, pp.76-115; e Sheila de Castro Faria, A colônia em movimento: fortuna e família no cotidiano colonial. Rio de Janeiro, Nova Fronteira, 1998, pp.52-8. 
da progressiva decadência de sua economia açucareira, que certamente impossibilitava a compra de africanos na mesma escala de Santo Amaro: assim, talvez a menor incorporação de forasteiros tenha estimulado a constituição de relacionamentos estáveis (sacramentados ou não pela Igreja); por outro lado, também é possível que os próprios escravos (ou ao menos alguns deles) resistissem ao casamento monogâmico. ${ }^{20}$ Somando-se a esses elementos a inoperância do clero, torna-se compreensível a pouca relevância do sacramento do matrimônio para a grande maioria dos cativos baianos no século XVII.

O matrimônio legitimamente constituído aos olhos da Igreja sofria ainda de outra limitação fundamental: praticamente todos os esposos, com exceção de apenas um, em Jaguaripe, pertenciam ao mesmo senhor, como em outras regiões e épocas. ${ }^{21}$ Em verdade, tal obstáculo aparentemente está presente mesmo para os relacionamentos informais estáveis (isto é, aqueles que geraram mais de um filho), pois encontramos apenas um casal (que gerou apenas dois filhos) entre pais de senhores distintos, sendo muito mais comum encontrar famílias informais dentro da mesma propriedade.

O maior proprietário das quatro paróquias é o desembargador Cristóvão de Burgos, com 35 inocentes batizados, dos quais cinco (14\%) legítimos; se, nas grandes propriedades, o maior número de cativos aumentava a possibilidade de enlaces formais, ainda assim eles continuavam a ser muito raros no século XVII, mostrando-se talvez privilégio de um pequeno grupo, interessado em se conformar com as normas católicas e capaz de pressionar de alguma maneira os senhores a reconhecerem formalmente suas uniões, já que implicavam, ao menos juridicamente, a proibição de separação dos parceiros e seu direito vitalício à coabitação - para além de, possivelmente, representarem uma marca de status dentro da hierarquia interna do cativeiro. É possível e provável, porém, que as lacunas simplesmente ignorem arranjos familiares internos da comunidade escrava, refletindo antes a dificuldade de formalizar as uniões (especialmente as que ultrapassassem os limites da propriedade) e, talvez,

\footnotetext{
20 Para a relação entre tráfico e família escrava, sintetizando e retomando pontos de seus trabalhos anteriores, cf. Manolo Florentino, "Tráfico atlântico, mercado colonial e famílias escravas. Rio de Janeiro, Brasil, c. 1790-c. 1830". História: Questões \& Debates, n.51 (2009), pp.69-119.

21 Schwartz, Segredos internos, p.313 e Faria, "Cotidiano do negro", pp.59-60.
} 
algum desinteresse dos próprios cativos no caráter vitalício e exclusivo da união católica, do que uma suposta anomia da comunidade escrava.

O jesuíta Antonil admite tal situação, afirmando mesmo que os senhores reconheciam o concubinato "dizendo: Tu Fulano a seu tempo casará com Fulana". ${ }^{22}$ Seu irmão de ordem, o italiano Antônio De Brandolini, encaminhou, em 1708, ao Sumo Pontífice um suposto memorial de uma irmandade de escravos africanos da Bahia (provavelmente a de Nossa Senhora do Rosário dos Pretos de Salvador, fundada em 1686) pedindo - sem sucesso - a intervenção papal para obrigar os proprietários a aceitar o casamento de seus cativos. ${ }^{23}$

É importante perceber, portanto, a possibilidade de matrimônios escravos como um diferencial entre a escravidão seiscentista e setecentista: se o casamento católico foi sempre acessível a (e/ou desejado por) apenas uma parcela restrita dos cativos, essa situação parece ter sido muito mais marcada no período de ascensão e consolidação da escravidão africana na Bahia, quando suas hierarquias costumeiras e seu modus vivendi ainda estavam em construção. Em acréscimo, é possível que a fragilidade e mesmo o descaso do aparato eclesiástico, especialmente no meio rural, tenha sido um dos fatores constituintes da extrema raridade do matrimônio católico entre os cativos, em oposição à sua ampla disseminação entre os livres, ${ }^{24}$ ainda mais se considerarmos que as primeiras diretrizes produzidas pela Igreja especificamente nesse sentido tenham surgido apenas no início do século XVIII, com as Constituições Primeiras do Arcebispado da Bahia (1707). ${ }^{25}$ Tais Constituições reconheciam que os

22 André João Antonil, Cultura e opulência do Brasil por suas drogas e minas, Lisboa: CNCDP, 2001 [1711], p.93.

23 Charlotte de Castelnau-L'Estoile, “O ideal de uma sociedade escravista cristã: direito canônico e matrimônio dos escravos no Brasil colônia", in Bruno Feitler e Evergton Sales Souza (org.), A Igreja no Brasil: normas e práticas durante a vigência das Constituições Primeiras do Arcebispado da Bahia (São Paulo: Ed. UNIFESP, 2011), pp.355-95.

24 Cf. Douglas Cole Libby, "As populações escravas das Minas setecentistas: um balanço preliminar", in Maria Efigênia Lage de Resende e Luiz Carlos Villalta (orgs.), História de Minas Gerais: as Minas setecentistas (Belo Horizonte: Autêntica, 2007), v.1, p.418.

25 José Pedro Paiva, "Os bispos do Brasil e a formação da sociedade colonial (1551-1706)", Textos de História, v.14, n.1/2 (2006), pp.26-30. Cf. também, para um detalhado panorama do cenário eclesiástico da Bahia, Pablo Antonio Iglesias Magalhães, "Equus Rusus: a Igreja Católica e as guerras neerlandesas na Bahia (1624-1654)" (Tese de Doutorado, Universidade Federal da Bahia, 2010), v.1, especialmente pp.349-401. 
senhores se opunham ao casamento de seus cativos e reafirmavam as disposições favoráveis ao matrimônio escravo constantes em decreto de 1568 do arcebispo de Lisboa e nas Constituições daquele arcebispado de 1646, ambas teoricamente vigentes no Brasil seiscentista, mas de nulo efeito prático. ${ }^{26}$

A Bahia de Seiscentos se contrapõe, assim, ao México, onde os sínodos provinciais trataram dessa questão desde meados do XVI, e os escravos frequentemente recorriam aos tribunais eclesiásticos para garantir o gozo do estado de casado. ${ }^{27}$ É claro que a grande quantidade de escravos concentrados no meio urbano e a força do aparato eclesiástico são fundamentais para explicar tal diferença, assim como a menor importância dos cativos na estrutura produtiva da Nova Espanha.

Mesmo assim, cabe reconhecer os limites de generalização dessas afirmações. Num dos poucos estudos sobre o século XVII, como o de Sheila de Castro Faria sobre a paróquia de São Gonçalo (1645-1668), no Recôncavo da Guanabara, 47,5\% dos escravos eram legítimos, ${ }^{28}$ taxa muito superior à que encontramos para as paróquias com registros sobreviventes na Bahia, inclusive Jaguaripe. Por que as diferenças? Como os numerosos trabalhos sobre o Setecentos deixam claro, variações significativas são comuns, forçando o pesquisador a reconhecer a especificidade das hierarquias costumeiras e os padrões demográficos de cada paróquia no Brasil escravista. Além disso, só uma análise sistemática sobre outras freguesias do Rio de Janeiro seiscentista pode esclarecer se São Gonçalo era regra ou exceção na capitania no tocante à questão da legitimidade dos inocentes cativos. Para além de variáveis de impossível verificação, como uma predisposição do pároco a estimular o matrimônio católico entre seu rebanho negro, é provável que o fato de o Rio de Janeiro ser menos ligado ao tráfico do que Salvador nesse período, recebendo cerca de $30 \%$ menos cativos em meados do XVII, o que

${ }^{26}$ Castelnau-L'Estoile. "O ideal de uma sociedade escravista cristã".

27 Hermann L. Bennet, Africans in Colonial Mexico: Absolutism, Christianity and Afro-Creole Consciousness, 1570-1640, Bloomington: Indiana University Press, 2003.

28 Faria, "Cotidiano do negro", p.37. A freguesia de Santo Antônio do Jacutinga apresentou índices similares na viragem do século XVII para o XVIII: Denise Vieira Demétrio, "Famílias escravas no Recôncavo da Guanabara: séculos XVII e XVIII" (Dissertação de Mestrado, Universidade Federal Fluminense, 2008), pp.116-8. 
fazia do africano uma mercadoria socialmente mais escassa, tenha sido um fator a estimular a formação de famílias formalmente reconhecidas, inclusive por possibilitar uma razão de sexo menos desbalanceada. Nesse sentido, podemos perceber semelhanças entre São Gonçalo e Jaguaripe, explicando a aparente excepcionalidade dessa paróquia em comparação com suas congêneres baianas.

Os estudos que utilizam os registros paroquiais para analisar a escravidão mencionam taxas reduzidas de alforrias na pia batismal, como para São João Del Rei, entre 1750-1850, entre 1\% e 3\%, ${ }^{29}$ Campos dos Goitacazes, $2 \%$ de 1753 a $1831^{30}$ e Vila Rica setecentista, 5\% a 6\%; porém, como percebeu Donald Ramos, "embora o número destes inocentes forros não fosse expressivo em termos demográficos, obviamente as alforrias concedidas na pia batismal eram importantes em termos sociais e culturais". ${ }^{31}$

Tais efeitos inexistiam na Bahia seiscentista, pois não encontramos sequer uma manumissão nos 1.774 batizados de inocentes cativos pesquisados. Não queremos dizer, é claro, que a alforria fosse uma impossibilidade, pois ela certamente existia desde o início da escravidão baiana. Entretanto, a presença discreta de livres e libertos de cor na documentação paroquial sugere fortemente que esse ainda era um grupo marginal, mesmo que com alguma capacidade de acumulação, a se julgar pela não desprezível contribuição das forras de Pernambuco para o donativo do dote da rainha da Grã-Bretanha e paz da Holanda, em 1664-1666. ${ }^{32}$

Há que se reconhecer a limitação inerente a esses dados, oriundos que são de quatro paróquias de características socioeconômicas distintas ao longo de quase um século, e registrados por párocos que demonstraram

29 Brügger, Minas patriarcal, p.296, nota 353.

30 Márcio de Sousa Soares, A remissão do cativeiro: a dádiva da alforria e o governo dos escravos nos Campos dos Goitacases, c. 1750-c. 1830, Rio de Janeiro: Apicuri, 2009, p.68.

31 Donald Ramos, "Teias sagradas e profanas: o lugar do batismo e compadrio na sociedade de Vila Rica durante o século do ouro", Varia História, n.31 (2004), p.47.

32 José Antônio Gonsalves de Mello (ed.), "A finta para o casamento da rainha da Grã-Bretanha e paz da Holanda", Revista do Instituto Histórico, Geográfico e Arqueológico Pernambucano, v.54 (1981), pp.9-62. 
Tabela 3 - Forros e livres de cor nos registros batismais da Bahia seiscentista (porcentagem do total)

\begin{tabular}{lrrrrr}
\hline & \multicolumn{1}{c}{ Mães } & \multicolumn{1}{c}{ Pais } & Padrinhos & Madrinhas & Senhores \\
\hline Jaguaripe (1613-1640) & $10(1,5 \%)$ & $2(0,3 \%)$ & $1(0,2 \%)$ & 0 & 0 \\
Jaguaripe (1641-1667) & $17(1,7 \%)$ & $18(2 \%)$ & $17(2,2 \%)$ & $9(1,3 \%)$ & $3(0,7 \%)$ \\
Purificação (1652-1676) & $12(1,2 \%)$ & $1(0,2 \%)$ & $53(5,5 \%)$ & $64(7,9 \%)$ & $5(0,9 \%)$ \\
Paripe (1672-1700) & $20(2,8 \%)$ & $5(1,7 \%)$ & $4(0,7 \%)$ & $8(2 \%)$ & 0 \\
Itaparica (1691-1700) & 0 & 0 & $4(4,5 \%)$ & $3(4,4 \%)$ & 0 \\
\hline
\end{tabular}

Fontes: Laboratório Eugênio da Veiga/Universidade Católica de Salvador, Registros de batismo das paróquias em análise (Purificação, Itaparica e Paripe digitalizados em www.familysearch.com).

um interesse variável na "cor" 33 e, por vezes, até mesmo no estatuto jurídico de seu rebanho. Mesmo assim, evidencia-se que, ao longo de todo o século, o número de forros e livres de cor (isto é, pretos, crioulos, mulatos e pardos) é muito menor do que o encontrado ao longo do Setecentos. Essa diferença é evidenciada pela comparação com Minas Gerais: entre 1712 e 1810, em Vila Rica, os filhos de mães forras representam 19\% do total, ${ }^{34}$ e, em São João del Rey, 17\% já em 1736-1740 e, nas décadas seguintes, entre $24 \%$ e $36 \%$. $^{35}$

As grandes diferenças entre as estruturas econômicas das duas áreas ajudam a explicar essa significativa disparidade. De qualquer maneira, porém, considerando-se que os filhos de mães forras ou de cor não ultrapassam 2,8\% já no final do Seiscentos em Paripe, não resta dúvida sobre o caráter incipiente e fortemente minoritário desse setor da sociedade, que virá a ser tão importante no século XVIII brasileiro.

Entretanto, sua maior proeminência em Paripe indica a tendência de lento crescimento dos livres de cor ao longo do Seiscentos. Tal desenvolvimento já é perceptível em meados do século em Jaguaripe, única paróquia cujos dados possibilitam uma análise de média duração. A

33 A dificuldade de identificação de forros é inevitável, como reconhecem Douglas Cole Libby e Tarcísio Botelho, "Filhos de Deus - batismos de crianças legítimas e naturais na Paróquia de Nossa Senhora do Pilar de Ouro Preto, 1712-1810", Varia Historia, n.31 (2004), p.73.

34 Libby e Botelho, "Filhos de Deus", p.87.

35 Brügger, Minas patriarcal, p.77. 
pequena quantidade de nascimentos significa que esse grupo dependia das alforrias para aumentar seu número. Embora as manumissões registradas em cartório na Bahia só sobrevivam a partir do final do século XVII, ${ }^{36}$ é provável que tenham sido restritas ao longo do século e se acelerado na transição para o Setecentos. ${ }^{37}$

O fator a explicar essa significativa alteração parece ter sido a grande intensificação do tráfico negreiro, num contexto de crescimento econômico e demográfico em todo o mundo atlântico, gerando a disseminação da propriedade escrava no Brasil, a facilidade de reposição de trabalhadores e o estímulo à concessão de alforrias para um melhor controle dos cativos, outorgadas principalmente por pequenos e médios proprietários. ${ }^{38}$

Assim, na primeira metade do Seiscentos, o grupo dos pardos e negros livres, responsável por uma das principais especificidades da escravidão brasileira no contexto americano, ainda era quase inexistente, só começando a se constituir como tal a partir de meados do século, como podemos ver em Jaguaripe e Santo Amaro, mas ainda de forma extremamente minoritária. ${ }^{39}$ Só na década de 1640, teria surgido a primeira irmandade de pardos na Bahia, ${ }^{40}$ mas ainda se tratava de confraria de cativos, o que já indica a pouca importância dos livres de cor nesse contexto. O próprio termo "pardo" só começa a aparecer nos registros paroquiais na década de 1650, primeiro em Santo Amaro

36 Schwartz, "Alforria na Bahia".

37 Como ocorreu no Rio de Janeiro: Antônio Carlos Jucá de Sampaio, “A produção da liberdade: padrões gerais das manumissões no Rio de Janeiro colonial, 1650-1750", in Manolo Garcia Florentino (org.), Tráfico, cativeiro e liberdade: Rio de Janeiro, séculos XVII-XIX (Rio de Janeiro: Civilização Brasileira, 2005), pp.287-329.

38 Rafael de Bivar Marquese, "A dinâmica da escravidão no Brasil: resistência, tráfico negreiro e alforrias, séculos XVII a XIX”, Novos Estudos CEBRAP, n.74 (2006), pp.107-26 e Soares, A remissão do cativeiro.

39 Processo similar parece ter ocorrido no Rio de Janeiro, ainda que com cronologia ligeiramente mais tardia. Cf. João Fragoso, "Apontamentos para uma metodologia em história social a partir de assentos paroquiais - Rio de Janeiro, séculos XVII e XVIII", 2012 (texto inédito).

40 Larissa Moreira Viana, O idioma da mestiçagem: as irmandades de pardos na América portuguesa, Campinas: Unicamp, 2007, pp.108-10. Note-se que em Lima de inícios do século XVII, por exemplo, existiam seis irmandades negras, três de mulatos e mais seis mistas, tendo sido a primeira fundada na década de 1540; em 1585, existiam mesmo mais irmandades de negros e "morenos" que de brancos e índios. Cf. Frederick P. Bowser, The African Slave in Colonial Peru, 1524-1650, Stanford: Stanford University Press, 1974, pp.247-51 e Karen Graubart, “'So color de una cofradía': Catholic Confraternities and the Development of Afro-Peruvian Ethnicities in Early Colonial Peru", Slavery \& Abolition, v.33, n.1 (2012), pp.43-64. 
(1652) e depois em Jaguaripe (1658), tornando-se mais comum a partir da década seguinte, em ambas as freguesias. Também nessa década, surge a primeira referência a uma companhia de ordenança dos "homens pardos" na Bahia, composta por livres de cor, datada de 14 de julho de 1655. ${ }^{41}$ "Mulato" continua a ser a classificação predominante, mas, em razão de sua conotação negativa, ${ }^{42}$ tende a ser utilizado para qualificar principalmente escravos, enquanto "pardo" é um termo utilizado cada vez com mais frequência para se referir a forros.

As referências a esse grupo se tornam mais pronunciadas nas últimas décadas do século em outros tipos de documentação, como uma petição "dos moços pardos da cidade da Bahia, solicitando se ordene aos religiosos da Companhia de Jesus os admitam nas suas escolas do Brasil sem embargo do seu nascimento e de sua cor". ${ }^{43} \mathrm{Ou}$, ainda, no parecer contrário do governador-geral Antônio Luís Gonçalves da Câmara Coutinho à pretensão de Pedro Ferreira da Fonseca de servir como meirinho em Salvador, pois "é homem pardo, e não parece razão que havendo Brancos sirvam os desta casta" ${ }^{44}$

Mesmo assim, cabe repetir que essas referências não se comparam à explosão do Setecentos, quando os livres de cor se tornaram onipresentes em todas as capitanias do Brasil. ${ }^{45}$ Assim, num contexto em que o tráfico negreiro ainda não havia alcançado o nível de importações do Setecentos e de uma menor diversificação produtiva, as possibilidades de ascensão social e mesmo de reprodução física dos livres de cor eram significativamente menores que no XVIII.

${ }^{41}$ Conde de Atouguia, Patente de capitão da companhia de ordenança dos homens pardos a Diogo Rodrigues Caldeira, 14/7/1655, DH, v.31, pp.170-1.

42 Cf. Ronald Raminelli, “Impedimentos da cor: mulatos no Brasil e Portugal, c. 1640-1750”, Varia Historia, v.28 (2012), pp.699-723.

43 Consulta do Conselho Ultramarino, 30/1/1689, Arquivo Histórico Ultramarino (AHU), Bahia, Luiza da Fonseca (LF), cx. 28, docs. 3517-9. A resposta régia, favorável, pode ser vista na provisão de 28/2/1689: José Justino de Andrade e Silva. Collecção Chronológica da Legislação Portugueza. Lisboa: Imprensa de J. J. A. Silva, 1854-9, v.X, p.189.

${ }^{44}$ Carta ao rei, 16/7/1692, Documentos Históricos da Biblioteca Nacional do Rio de Janeiro: Rio de Janeiro: Biblioteca Nacional, 1928-2011, (DH), v.34, p.25.

45 Silvia H. Lara. Fragmentos setecentistas: escravidão, cultura e poder na América portuguesa. São Paulo: Companhia das Letras, 2007. Para uma detalhada análise local desse processo, cf., em perspectiva distinta, Ana Paula Cabral Tostes, “O lugar social dos homens 'pardos' no cenário rural da Cidade do Rio de Janeiro: Recôncavo da Guanabara, Freguesia de Nossa Senhora do Desterro de Campo Grande, Século XVIII" (Dissertação de Mestrado, Universidade Federal do Rio de Janeiro, 2012). 
Por outro lado, é preciso reconhecer que já em meados do Seiscentos é possível encontrar alguns casos em que pardos livres conseguiam se livrar do estigma da cor, ${ }^{46}$ ao que parece sem muita dificuldade. Analisemos o exemplo de Francisco Gonçalves: nascido em 1624, filho natural de João Gonçalves (senhor de poucos cativos) e Lucrécia (muito provavelmente escrava de João), é classificado como pardo uma única vez, quando leva para a pia batismal Bárbara, a primeira de suas duas filhas naturais com Luzia, de Isabel de Costa, em 1659. Mesmo assim, Francisco manteve certa proximidade com o cativeiro, pois teve outra filha com uma escrava mulata e, mais importante, apadrinhou quadro crianças escravas (duas delas pertencentes a seu pai). Isso, ao que parece, não atrapalhou suas relações com o mundo dos livres, pois também apadrinhou três filhos legítimos de livres, além da progênie de um casal de índios. Uma das cativas que Francisco apadrinhou foi Helena, filha de Madalena, sendo João Vieira, pardo, apontado como pai da criança. Ao que parece, nascimentos ilegítimos eram uma ocasião privilegiada para apontar a cor de paroquianos, pois nos outros momentos em que João Vieira surge na documentação, como proprietário de quatro cativos, padrinho de outros cinco e pai de três crianças legítimas, sua cor não entra em questão. $O$ estigma não se fazia constantemente presente, mas podia surgir em momentos em que o indivíduo se desviasse da norma; por outro lado, mesmo dormente estimulava o estabelecimento de laços - ainda que hierárquicos - com o mundo dos cativos.

Se a concessão de alforrias tem sido longamente reconhecida como uma das diferenças fundamentais entre os sistemas escravistas montados pelas potências ibéricas e o mundo atlântico norte-europeu, ${ }^{47}$ pesquisas recentes têm demonstrado que, até meados do Seiscentos, a obtenção da liberdade não era uma possibilidade ilusória em diversas possessões inglesas.$^{48}$ As diferenças entre os sistemas escravistas já existiam, mas ainda estavam crescendo para atingir o forte contraste do século XVIII.

${ }^{46}$ Cf., dentre outros, Faria, A colônia em movimento, pp.135-40.

47 Frank Tannembaum, Slave and Citizen: the negro in the Americas, Nova York: Vintage Books, 1946.

48 Ira Berlin, Gerações de cativeiro: uma história da escravidão nos Estados Unidos. Rio de Janeiro: Record, 2006, pp.33-65 e Linda Heywood e John Thornton, Central Africans, Atlantic Creoles, and the Foundation of the Americas, 1585-1660, Cambridge: Cambridge University Press, 2007, pp.294-331. 


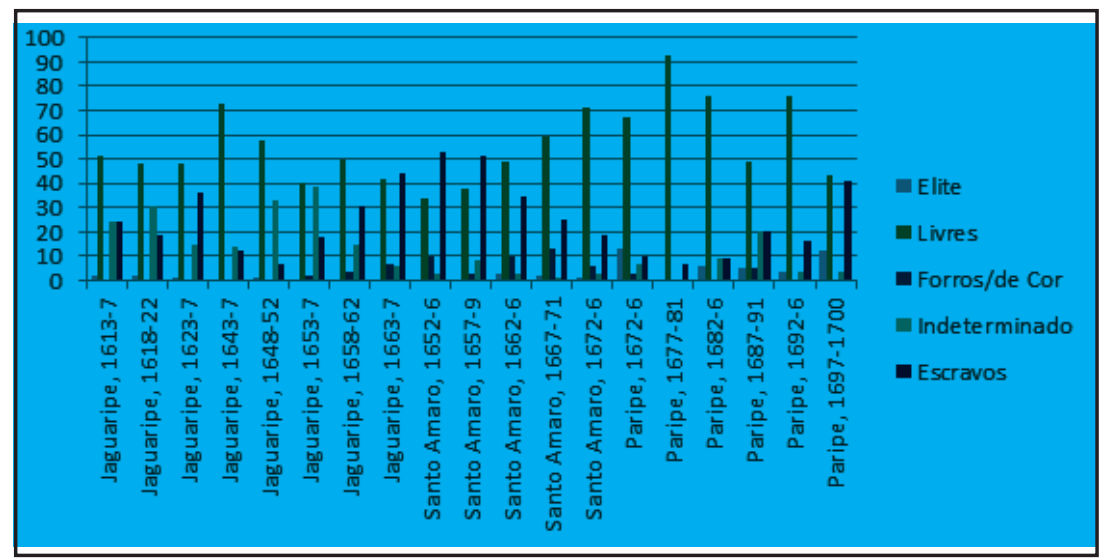

\section{Gráfico 1 - Classificação social dos padrinhos de cativos (\%)}

Fontes: Laboratório Eugênio da Veiga/Universidade Católica de Salvador, Registros de batismo das paróquias em análise (Santo Amaro, Itaparica e Paripe digitalizados em www.familysearch.com)

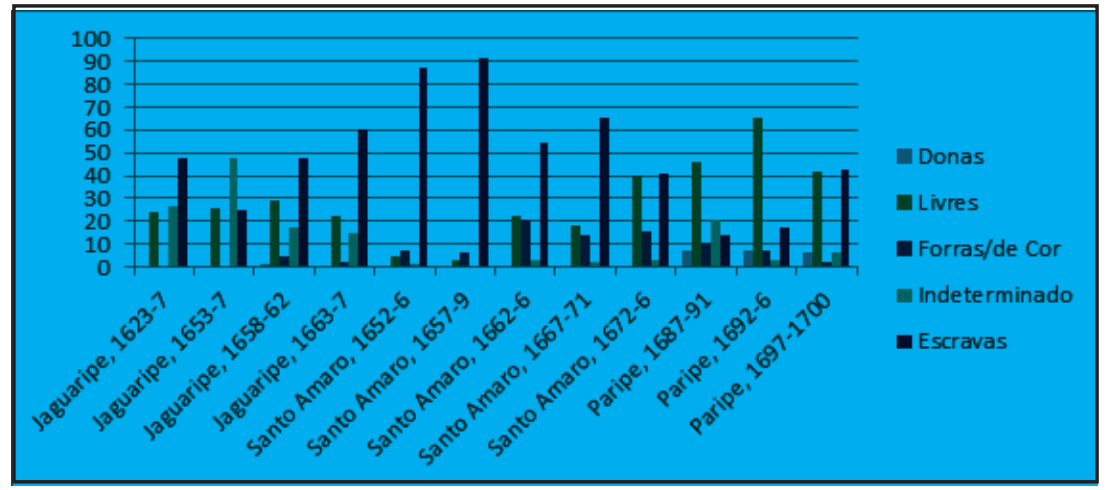

\section{Gráfico 2: Classificação social das madrinhas de cativos (\%)}

Fontes: Laboratório Eugênio da Veiga/Universidade Católica de Salvador, Registros de batismo das paróquias em análise (Santo Amaro, Itaparica e Paripe digitalizados em www.familysearch.com).

Assim, nos dois primeiros séculos de colonização era provavelmente na América Espanhola, e não no Estado do Brasil, que seria possível 
encontrar as maiores taxas de manumissão e de inclusão dos africanos e seus descendentes na comunidade civil através da Igreja. ${ }^{49}$

Os gráficos 1 e 2 possibilitam nos aprofundarmos na análise das relações sociais estabelecidas com o parentesco espiritual. Cabem, porém, algumas ressalvas. Os intervalos de cinco anos foram escolhidos na tentativa de apreender mudanças e transformações dentro de uma mesma paróquia. Entretanto, em busca de um mínimo de representatividade, foram excluídos do gráfico os intervalos para os quais há menos de 25 casos ou em que os indeterminados ultrapassassem 50\% do total. Quem são os padrinhos e madrinhas "indeterminados"? São aqueles que, nos batismos, aparecem da seguinte maneira, para citar um exemplo: “em 3 de novembro de 1675, batizei e pus os santos óleos em Simão, filho de Antônia, escrava de Cristóvão de Burgos, e foram padrinhos Baltazar e Maria”. No caso de Jaguaripe, creio que vários deles são indígenas, frequentemente referidos somente pelo primeiro nome. Talvez alguns sejam forros, mas pensamos que a maioria é composta por escravos do senhor do batizando, de modo que a propriedade ficaria subentendida pelo pároco e seu rebanho, e não seria preciso mencioná-la explicitamente. É de se notar que, justamente na paróquia em que os indeterminados têm uma importância apenas residual, Santo Amaro, a quantidade de forros é um pouco maior, mas o principal grupo que cresce é o de escravos, como é perceptível ao examinarmos a elevada percentagem de madrinhas escravas nessa freguesia.

Por último, é preciso definir o que entendemos como elite, para os efeitos dessa análise: para as mulheres, a titulação "dona”, atribuída pela comunidade a partir do pároco, geralmente é um indicador seguro de pertencimento ao estrato superior da localidade e ao grupo que, ao longo do Seiscentos, se constituiu como uma nobreza. ${ }^{50}$ Sua raridade

49 Bennet, Africans in Colonial Mexico e Bowser, The African Slave.

50 Para uma análise do que significava ser "dona" no Rio de Janeiro dos séculos XVII e XVIII, cf. Fragoso, "Efigênia", pp.80, 90-1, 100 e 102 (nota 19). O significado do termo conhecia variações no Império português, como no caso angolano, mas seu caráter de preeminência social parece indiscutível: cf. Selma Pantoja, "Laços de afeto e comércio de escravos. Angola no século XVIII", Cadernos de Pesquisa do CHDHIS, v.23, n.2 (2010), pp.381-2; Renato Pinto Venâncio, Maria José Ferro de Sousa e Maria Teresa Gonçalves Pereira, "O Compadre Governador: redes de compadrio em Vila Rica em fins do século XVIII”, Revista Brasileira de História, v.26, n.52 (2006), p.282 e Paula Roberta Chagas, "Usos cotidianos do parentesco espiritual: Curitiba na transição do século XVII para o XVIII” (Dissertação de Mestrado, Universidade Federal do Paraná, 2010), p.45. 
é perceptível quando notamos que, em Santo Amaro da Purificação, apenas 18 (4\%) dos 456 apadrinhamentos por mulheres livres sem cor foram protagonizados por "donas". Elite, por outro lado, é um termo de definição bem mais difícil e mais sujeito a questionamentos: utilizamos essa classificação aqui para nos referir aos membros da açucarocracia (senhores de engenho, lavradores ricos e seus parentes próximos), irmãos de maior condição das Misericórdias, os principais oficiais camarários e os detentores dos mais altos postos na administração periférica, na tropa paga e, principalmente, na ordenança, pois seus oficiais estão entre as figuras mais presentes no cotidiano das freguesias rurais dos séculos XVII e XVIII. ${ }^{51}$

Nas sociedades católicas do mundo luso, o compadrio deve ter atuado desde o início da formação dessa sociedade escravista americana como uma forma de integração social, sendo a única a ligar cativos e livres institucionalmente. Já em Jaguaripe, entre 1613 e 1627, cerca de metade dos padrinhos de escravos é livre, numa proporção que se mantém mais ou menos constante até o fim do período coberto pelos registros dessa freguesia (apesar de algumas variações, possivelmente resultado do pequeno número de registros em termos absolutos, como entre 1643 e 1647, quando 73\% (41) dos padrinhos eram livres).

Ao observarmos o gráfico, porém, é possível perceber que, em outras freguesias, ocorreram maiores oscilações, que podem ser resultado de lacunas documentais, dos costumes locais ou da influência dos párocos: ${ }^{.52} \mathrm{em}$ Santo Amaro, especificamente, a porcentagem de padrinhos e madrinhas livres aumentou continuamente de 34\% (33 casos) e 5\% (5), respectivamente, em 1652-1656 para 71\% (78) e 40\% (39) em 1672-1676. Somando-se a esses números os de forros e livres de cor, percebe-se que os escravos, antes majoritários, perdem (inclusive entre as mulheres) a posição cimeira, situação que se mantém em Paripe, até o final do século. Talvez o que esses dados estejam indicando seja uma lenta mas contínua intensificação das relações hierarquizantes entre livres e escravos nesse período de consolidação da escravidão africana.

${ }^{51}$ Cf. Thiago Krause, Em busca da honra: a remuneração dos serviços da guerra holandesa e os hábitos das Ordens Militares (Bahia e Pernambuco, 1641-1683). São Paulo: Annablume, 2012, pp.232-3.

52 Para variações similares, mas ainda mais pronunciadas, em localidades muito próximas, cf. Guido Alfani, Fathers and Godfathers: Spiritual Kinship in Early Modern Italy, Farnham: Ashgate, 2009. 
Tal tendência parece ter afetado também a participação da elite baiana no apadrinhamento dos cativos. Embora alguns membros isolados da elite tenham apadrinhado escravos em Jaguaripe e em Santo Amaro, essa situação só se torna um pouco mais comum em finais do século em Paripe, alcançando $12 \%$ dos padrinhos ( 10 casos) e $6 \%$ das madrinhas (4), ainda que permaneça fortemente minoritária, inclusive em comparação com o apadrinhamento de livres, pois $38 \%$ dos livres batizados em Paripe tiveram "donas" como madrinhas. Tal estratégia devia reforçar laços com alguns setores da senzala, embora seja impossível aquilatar sua importância sem mais fontes; em ao menos alguns casos, deve ter sido uma forma de estender proteção a filhos de parentes ou aliados, já que, em 17 dos 20 casos, em Paripe, os filhos são de pai desconhecido, podendo compor uma descendência ilegítima da família do padrinho. Cabe notar, porém, que nenhum dos homens mais destacados dessas paróquias apadrinhou cativos, caso dos grandes potentados locais, o Desembargador Cristóvão de Burgos e o Capitão Francisco Fernandes Dosim.

Os dados estatísticos sobre a distribuição de padrinhos em Santo Amaro reforçam os padrões encontrados em estudos anteriores, de predominância de padrinhos livres e madrinhas escravas. A primeira escolha era uma forma de estabelecer ou formalizar alianças verticais, e as comadres cativas podiam cimentar laços dentro da comunidade escrava, importantes para a criação dos rebentos. $\mathrm{O}$ alcance das relações pessoais dos cativos é perceptível quando notamos que, para além de livres e forros, também foram estabelecidos (com destaque para Santo Amaro) laços de parentesco espiritual interpropriedades, especialmente recorrentes quando havia relações de parentesco entre os senhores, como no caso de Bento, propriedade do Capitão Pedro Aranha, apadrinhado em 1659 por dois cativos do Capitão Francisco Fernandes Dosim, avô de Pedro. Nesse caso, é muito provável que os escravos estivessem em propriedades contíguas — ou até em uma só grande fazenda que englobava diversas posses, como o engenho do capitão Dosim. É possível que existam outros casos como este, mas não consigo identificá-los em vista da escassez de fontes.

Como todas as madrinhas livres "sem cor" (portanto, supostamente brancas) fazem par com livres também sem cor, o maior número de padrinhos livres em todos os recortes significa que muitos desses padrinhos 
livres tiveram comadres cativas ou forras, o que pode ter potencializado as possibilidades de ascensão dentro e fora do cativeiro dessas mulheres, ao criar canais de comunicação com o mundo livre.

Tal pareamento é especialmente evidente em Santo Amaro, onde, em 122 batizados, madrinhas cativas acompanharam padrinhos livres. Em 30 desses casos, os padrinhos são forros ou livres de cor: destacam-se aqui os pardos (20), e depois os pretos (quatro), mulatos (três) e crioulos (três). Se, ao mesmo tempo, isso pode indicar a predominância dos pardos entre os livres de cor, também pode sinalizar seu prestígio no apadrinhamento dos cativos - o que, por sua vez, nos dá pistas sobre seu papel na hierarquia social costumeira da região. No caso das madrinhas, das 19 com origem identificada, 10 são africanas, cinco mulatas e quatro crioulas.

Nos 92 casos restantes, 47 são de madrinhas mulatas e quatro de pardas, compondo mais da metade dos casos de pareamento entre livres sem cor e madrinhas cativas, numa proporção muito superior àqueles entre as que tiveram como companheiros na pia batismal os livres de cor - e também, certamente, sua participação na população escrava como um todo. Em oposição, na mesma paróquia, somente cinco madrinhas mulatas ou pardas foram acompanhadas por padrinhos cativos. Quatro foram classificados como mulatos ou pardos e, dentre esses, três eram cativos de figuras importantes na elite baiana: dois sargentos-mores e o capitão Antônio Guedes de Brito, um dos homens mais ricos e poderosos da capitania, destacado no serviço real e no governo da República nas décadas de 1660 e 1670, tendo atuado como vereador, juiz ordinário, provedor da Misericórdia e até membro do Governo-Geral provisório. ${ }^{53}$

Também nesse aspecto, portanto, as cativas de origem miscigenada possuíam uma nítida vantagem, indicando mais um elemento de hierarquização dentro do cativeiro. Em três casos, é notável a popularidade

53 Cf., dentre outras, Carta de Hábito, Alvará de Profissão de Alvará de Cavaleiro de Antônio Guedes de Brito, 07/05/1676: IAN/TT, Chancelaria da Ordem de Cristo (COC), L. 54, fls. 15-16; Luís Amaral (ed.). Livros de Matrículas dos Moradores da Casa Real: foros e oficios, 1641-1744. Lisboa: Guarda-Mor, 2009, vol. II, p.429; Carta de Antônio Guedes de Brito ao governador-geral Afonso Furtado de Mendonça, 30/12/1673: DH, v.8, pp.393-4 e Governador-Geral Alexandre de Sousa Freire, Patente de Mestre de Campo de Infantaria a Antônio Guedes de Brito, DH, v.24, p.99; Pedro Calmon (ed.). Introdução e notas ao Catálogo Genealógico das Principais Famílias de Jaboatão. Salvador: Empresa Gráfica da Bahia, 1985, pp.207-9. 
de madrinhas mulatas: Joana, de Francisco de Brito de Góis, da nobreza baiana, que apadrinha cinco inocentes de cinco senhores diferentes juntamente com cinco padrinhos distintos; e duas Marias, de José da Silva Ribeiro e Maria da Mota, madrinhas de quatro crianças cada, nas mesmas condições de Joana. Essas três cativas foram as escravas com mais afilhados em Santo Amaro da Purificação, mas jamais tiveram como parceiro na bia batismal um cativo, dado que muito provavelmente indica uma posição social diferenciada frente ao restante da escravaria.

Tratando agora dos inocentes, em Santo Amaro, os cativos classificados como "crioulos" tinham apenas 24\% (31) de chances de serem apadrinhados por livres sem cor — proporção inversa aos "mulatinhos", que tiveram padrinhos dessa condição em 79\% (124) dos casos. Mesmo quando os padrinhos eram cativos, é possível notar-se uma diferenciação: sete dos 15 padrinhos escravos de inocentes miscigenados são mulatos, quase a metade, enquanto somente cinco de 77 dos "crioulinhos" foram assim classificados. Em Jaguaripe, dos 118 filhos com pais livres identificados entre 1641 e 1667, somente três foram apadrinhados por cativos.

Percebe-se, assim, como, desde o início da vida, a conexão desses escravos miscigenados com o mundo livre era muito mais intensa que a de seus companheiros de cativeiro negros, provavelmente potencializando a capacidade de membros desse grupo de obter alforria, como já se demonstrou para outras regiões. ${ }^{54}$ Provavelmente, mais do que a cor da pele, eram as relações sociais estabelecidas com livres que distinguiam esses cativos do restante da escravaria, facultando-lhes, por exemplo, o acesso a ofícios especializados ou ao serviço doméstico.

Ao que parece, em Paripe, as hierarquias sociais costumeiras não favoreciam a consolidação dos laços horizontais entre cativos (com exceção do período entre 1697-1700, após a mencionada repreensão do visitador), sendo a função principal do compadrio o estabelecimento de relações verticais entre os escravos, padrinhos e senhores - como no caso de Diogo Pereira, que batiza cinco cativos, dentre os quais um do Desembargador Cristóvão de Burgos, outros de Clara Pereira, João

54 Para a alforria na pia batismal e mestiçagem, cf. Tostes, "O lugar social", p.50 e Soares, A remissão do cativeiro, p.71; para descobertas similares nos batismos do Rio de Janeiro, Fragoso, "Apontamentos". 
Borges de Abreu e Duarte Lobo da Gama, todos dentre os principais proprietários da freguesia.

Burgos, porém, destaca-se claramente do restante, sendo um personagem recorrente na historiografia sobre a Bahia seiscentista. Seu pai era o licenciado Jerônimo de Burgos, descendente de uma proeminente família de livreiros em Évora (tendo exercido essa profissão na juventude, antes de emigrar para o Brasil). Jerônimo, ao chegar a Salvador, casou-se com a baiana Dona Maria Pacheco e tornou-se proprietário de um engenho em mau estado e juiz dos órfãos (ofício recebido em dote, exercido a partir de 1617), procurador dos feitos da Coroa, Fazenda e Fisco entre 1630 e 1646, provedor da Santa Casa e, em 1627 e 1633, vereador. ${ }^{55}$

O fundador da família Burgos na Bahia demonstrou um temperamento difícil, envolvendo-se em diversos conflitos, especialmente ao ser acusado de se locupletar da fazenda dos órfãos. ${ }^{56}$ Foi capaz, porém, de deixar seus filhos em boas condições: Gaspar Pacheco e Antônio de Burgos tornaram-se capitães, cavaleiros de ordens militares e se casaram com "donas". ${ }^{57} \mathrm{O}$ destino mais ilustre, porém, estava reservado a Cristóvão, que estudou na Universidade de Coimbra e seguiu a carreira jurídica até obter a desejada nomeação para a Relação da Bahia, como desembargador e ouvidor-geral do crime. Casou-se com Dona Helena da Silva Pimentel, irmã do potentado Antônio da Silva Pimentel, alcaidemor de Salvador, tornou-se senhor de três engenhos e diversas fazendas, utilizando seu poder e influência para, sempre que possível, se recusar a pagar o dízimo para a Fazenda Real e, principalmente, as contribuições e donativos cobrados pela Câmara — o que gerou, em 1686, reclamações

55 Cf., dentre outros, Calmon, Introdução e notas, pp.243-4, 249-50, 372 e 533-4; Consultas de mercês do Conselho Ultramarino, 21/07/1645 e 19/12/1646, AHU, cód. 79, fls. 16-17; cód. 80, fls. 320-320v.

56 Cf., por exemplo, Consultas do Conselho Ultramarino, 13/10/1645 e 27/01/1662, AHU, BA, LF, cx. 10, docs. 1150-2 e cx. 16, doc. 1832.

57 Calmon, Introdução e notas, pp.371-4 e 533-4; Consultas de mercê do Conselho Ultramarino, c. 1645, 20/10/1652, 06/10/1653: AHU, cód. 79, fls. 17v-18; cód. 82, fls. 141v-142 e 265-6; Consultas da Mesa de Consciência e Ordens, 29/01/1662 e 02/03/1662: IAN/TT, Habilitações da Ordem de Avis, Letra A, mç. 2, n.14; Carta de Hábito, Alvará de Cavaleiro e Alvará de Profissão para Gaspar Pacheco Contreiras, 10/03/1657: Chancelaria da Ordem de Avis, L. 14, fls. 664v-665 e Carta de Hábito, Alvará de Cavaleiro e Alvará de Profissão para Antônio de Burgos Contreiras, 18/04/1662: L. 15, fls. 54-54v. 
dos fregueses de Paripe, obrigados a pagar mais para compensar a isenção do desembargador, mas sem sucesso. ${ }^{58}$ Tal pertinácia não impediu que se tornasse provedor da Santa Casa em 1665, cavaleiro da Ordem de Cristo em 1672 e um dos governadores provisórios após a morte de D. Afonso Furtado de Mendonça, entre 1675 e 1677, quando tinha pouco menos de sessenta anos de idade. ${ }^{59}$

É nesse período de auge do poder de Burgos que o encontramos como principal proprietário em Paripe, senhor dos dois únicos engenhos da freguesia e de mais cinco fazendas, tendo batizado 35 inocentes entre 1672 e 1700, filhos de 20 mães distintas. Dez crianças não tiveram padrinhos e somente seis foram apadrinhadas por escravos, todos de propriedade do próprio desembargador. As 19 restantes tiveram homens livres como padrinhos, sendo apenas um dos parentes rituais um pardo forro, Manoel, que também tomou sob sua proteção espiritual um inocente de Manoel Teles Barreto em 10 de junho de 1691, tratando-se possivelmente de um forro de uma das duas casas.

Portanto, 18 dos 25 padrinhos são livres "sem cor", o que significa, em princípio, que eram brancos. Por que esses homens decidiram apadrinhar os cativos do desembargador? A maioria aparece somente nessa ocasião nos registros paroquiais, ou ainda uma única outra vez, tratando-se talvez de agregados ou homens livres pobres vivendo à sombra do potentado. A não recorrência desses homens na série documental pode resultar, por outro lado, da mobilidade característica dos grupos subalternos livres no período colonial, ${ }^{60}$ evidenciando uma das muitas limitações do tipo de fontes utilizado. É o caso, por exemplo, de Antônio de Barros, que só surge em 10 de outubro de 1681, quando tomou sob sua proteção Ângela, filha de Francisca, junto com Serafina, parda de Burgos, assim como outros nove padrinhos e madrinhas. Talvez

58 Carta da Câmara de Salvador ao rei D. Pedro II, 20/07/1686, Documentos Históricos do Arquivo Municipal: Cartas do Senado, v.III, pp.30-1 e Carta do Rei D. Pedro II à Câmara de Salvador, 14/11/1686: AHMS, PR, v.III, fl. 40.

59 Processo de Habilitação de Cristóvão de Burgos, c. 1644: IAN/TT, Leitura de Bacharéis, Letra C, mç. 2, n.55; Carta de Hábito, Alvará de Cavaleiro e Alvará de Profissão para Cristóvão de Burgos, 13/05/1670: COC, L. 56, fls. 415-415v e Padrão de Tença para Cristóvão de Burgos, 29/12/1681: L. 73, fls. 182-184; Calmon, Introdução e notas, pp.533-5; Schwartz, Segredos internos, p.227.

${ }^{60}$ Faria, A colônia em movimento, pp.101-14. 
essas relações de compadrio acontecessem primariamente em razão da proximidade entre cativos e livres pobres, aproximados pelo cotidiano da labuta e pobreza rural.

Outros casos, porém, são mais enigmáticos. O licenciado Estevão Gomes de Escobar, filho de mercador (e, talvez, mercador ele mesmo), escrivão da Misericórdia em 1675, vereador em 1678 e capitão de uma das companhias de ordenança da freguesia da Praia na mesma cidade, ${ }^{61}$ teve dois filhos em Santo Amaro apadrinhados pelo Capitão Felipe de Moura de Albuquerque (em 1666) e pelo Sargento-Mor Antônio de Brá (1675), o primeiro senhor de engenho, alcaide-mor, provedor da Santa Casa e comendador, e o segundo irmão da Misericórdia e cavaleiro da Ordem de Cristo. ${ }^{62}$ Em Paripe, Escobar apadrinhara, em 2 de setembro de 1685 e 18 de novembro de 1686, dois filhos de Constantino Muniz Teles e Dona Teresa de Lacerda Coutinho (sobrinha de sua esposa), membros de antigas famílias da nobreza baiana. Ele e sua mulher, Ângela Paes de Azevedo (de família tradicional desde o início do Seiscentos, embora não especialmente proeminente, sendo neta de um lavrador de cana), ${ }^{63}$ levaram seis escravos de sua propriedade para a pia batismal em Paripe entre 1686 e 1693. Tratava-se, portanto, de um casal bem situado na sociedade baiana: mesmo assim, em 21 de março de 1700, Escobar apadrinhou Guilherme, filho de Joana, cativa do desembargador.

O estabelecimento dessa relação pode ter sido iniciativa tanto do padrinho quanto do senhor, mas é improvável que tenha sido de Joana, já que não parece crível que ela compartilhasse um espaço de sociabi-

61 Governador-Geral Alexandre de Sousa Freire, Carta Patente de Capitão de Ordenança a Estevão Gomes de Escobar, 15/07/1668: DH, vol. 11, pp.430-2 e Provedor da Fazenda Lourenço de Brito Correia, Auto de Vistoria sobre obra do licenciado Estevão Gomes de Escobar, 13/09/1664: vol. 21, p.422-8; Luiza da Fonseca, "Bacharéis brasileiros: elementos biográficos", in Anais do IV Congresso de História Nacional, Rio de Janeiro: Imprensa Nacional, 1951, v.9, pp.141-2; Ata da Câmara de Salvador, 22/06/1668: Documentos Históricos do Arquivo Municipal: Atas da Câmara. Salvador: Prefeitura Municipal, 1949-2011, 11 volumes, v. V, 1669-84. Salvador, 1950, pp.233-4; Calmon, Introdução e notas, pp.501 e 505.

62 Provedor-Mor da Fazenda Pedro Cadena Vilhasanti, "Memória dos senhores de engenho a quem se mandou fazer lancha", c. 1639: João Paulo Salvado \& Susana Münch Miranda (eds.). Cartas do $1^{\circ}$ Conde da Torre. Lisboa: CNCDP, 2001, v. II, p.198-9; Vice-Rei Conde de Óbidos, Carta Patente de Alcaide-Mor a Felipe de Moura de Albuquerque, 01/07/1664: DH, vol. 21, pp.391-2; Carta de Hábito de Francisco de Brá, 23/12/1665: COC, L. 18, fls. 267; Calmon, Introdução e Notas, pp.61-4 e 733-5.

${ }_{63}$ Calmon, Introdução e notas, pp.501-5. 
lidade com Escobar. Fosse qual fosse o motivo, é muito provável que esse apadrinhamento significasse o reforço de uma relação entre os dois idosos nobres letrados, sem filhos recém-nascidos que pudessem ser utilizados para os transformarem em compadres. Tal relacionamento, porém, era assimétrico, estando Burgos numa posição superior, como senhor do cativo que deu origem a essa relação.

A hierarquia, porém, se mostra de maneira mais evidente em outros casos, como no de João Gomes da Silva, único a apadrinhar dois cativos do desembargador: Mariana, em dois de abril de 1690, e Poliana, em 11 de dezembro de 1695. Diferentemente de Escobar, João estava habituado a ser padrinho de cativos: entre 1686 e 1689, tomou sob sua proteção espiritual quatro inocentes. Não se restringiu, porém, à senzala: nesses anos, apadrinhou também três crianças de livres sem classificação social. Mais interessante, porém, é que, em 1689, apadrinhou José, filho de Manoel Gomes de Escobar (filho de Estevão) e Dona Jerônima de Menezes (da nobre família dos Barbudas, entre os primeiros povoadores da Bahia); em 1691, Ana, filha de Francisco de Freitas e Dona Margarida, junto de sua mulher; e, em 1696, Ana, filha de Pedro de Freitas de Magalhães e Dona Mariana de Vasconcelos. Entre 1691 e 1699, também batizou seis filhos, obtendo a patronagem de figuras importantes: primeiro, o vigário da paróquia, Antônio Gomes da Silva, que propiciou a primeira aparição de João na série, quando esse batizou a escravinha Isabel, de propriedade do padre, e provavelmente era seu parente, mesmo porque apadrinhou quatro dos seis filhos de João; a esposa de Estevão Gomes de Escobar, Ângela Paes de Azevedo, amadrinhou duas crianças, o coronel Francisco Pereira Botelho, outra, e Dona Helena da Silva Pimentel (em 1694), Jerônimo de Burgos Pacheco (sobrinho de Cristóvão) e sua esposa Dona Helena de Oliveira Melo (em 1699) mais duas. Ainda entre 1695 e 1699, entrou na classe dos escravagistas, pois duas cativas suas deram a luz a cinco crianças - todas batizadas por livres, exceto uma, que teve como madrinha uma escrava de Clara Pereira (ela mesma senhora de oito inocentes).

Ou seja, em 1689, João Gomes da Silva praticamente deixa de apadrinhar escravos e livres sem classificação para se imiscuir no mundo da nobreza baiana, estabelecendo uma ampla rede de relações. Pela cro- 
nologia, parece-nos muito provável que essa virada esteja intimamente relacionada com a sua inserção subalterna na rede de Burgos: se era impossível tornar-se compadre dele diretamente, faz-se o melhor possível, apadrinhando seus cativos, o que serviu como um ponto de partida para, aí sim, tornar-se compadre da esposa do potentado e de seu sobrinho.

Caso similar é o de Miguel de Gouveia, que aparece pela primeira vez em Jaguaripe, em 26 de julho de 1647, tendo seu filho João batizado pelo Capitão Gaspar Borges da Vide e por Dona Catarina de Sande, filha do Capitão Francisco Fernandes Dosim, "o mais rico homem do Brasil", grande negociante, senhor de engenho, cavaleiro de Santiago e Provedor da Misericórdia por cinco anos; ${ }^{64}$ menos de um mês depois, apadrinha um filho de Petronilha, cativa do mesmo Capitão Francisco Fernandes. Insere-se, assim, de forma subalterna, na rede do principal potentado da freguesia, tornando-se, posteriormente, senhor de dois cativos levados à pia batismal e padrinho de quatro crianças livres legítimas.

Evidencia-se, portanto, o caráter múltiplo do compadrio entre livres e escravos: esse tanto podia ser utilizado para reforçar laços entre livres pobres e cativos, marcados mais pela proximidade que pela hierarquia, quanto como um mecanismo para que membros da elite (e aspirantes a ela) estabelecessem relações indiretas. A própria dispersão de padrinhos e madrinhas, comum tanto a Burgos quanto a Dosim, podia ser uma estratégia para estabelecer uma ampla rede com pessoas a quem não consideravam necessário ou conveniente agraciar com um apadrinhamento (cabe notar que todos os oito afilhados de Burgos em Paripe eram filhos de "donas"). Esses potentados conseguiam, assim, se relacionar com os variados segmentos livres da sociedade — porque, ao que parece, não consideravam outros escravos dignos de apadrinhar ou serem apadrinhados por seus cativos, pois, apenas dois escravos de cada um dos potentados aparecem como padrinhos ou madrinhas de cativos de outros senhores, e somente um escravo de Dosim é apadrinhado por um cativo de outro senhor.

Atualmente, os trabalhos sobre compadrio têm procurado cruzar as

${ }^{64}$ David Grant Smith, "The Mercantile Class of Portugal and Brazil in the Seventeenth-Century: a Socio-Economic Study of the Merchants of Lisbon and Bahia, 1620-1690" (Tese de Doutorado, Universidade do Texas, 1975), pp.314-25. 
fontes paroquiais com testamentos, inventários, listas populacionais, etc. ${ }^{65}$ Entretanto, para o século XVII, os registros paroquiais são praticamente as únicas fontes sobreviventes para o estudo da sociedade agrária e escravista que então se consolidava. Desse modo, precisam ser exploradas intensamente para que delas possamos extrair o máximo, na tentativa de ampliar nosso entendimento sobre a sociedade luso-americana seiscentista. Daí a importância de realizarmos estudos de caso como os acima, na tentativa de ultrapassar as limitações inerentes a uma análise estatística que transforma em gráficos e números relações pessoais vividas pelos agentes históricos, que, por mais que fossem imateriais e espirituais, não deixavam de ser muito reais.

Recebido em 13 de agosto de 2013 e aprovado em 23 de dezembro de 2013

65 Como enfatiza Carlos de Almeida Prado Bacellar, "Os compadres e as comadres de escravos: um balanço da produção historiográfica brasileira". Anais do XXVI Simpósio Nacional de História, São Paulo: ANPUH, 2011. 


\section{Resumo}

A partir do estudo do compadrio em quatro paróquias rurais na Bahia, entre 1613 e 1700, são examinadas as especificidades do período de consolidação da escravidão na principal capitania açucareira do Estado do Brasil. Por meio de uma análise quantitativa, demonstra-se a reduzida relevância demográfica dos forros, o prestígio de pardos e mulatos dentro do próprio cativeiro e a raridade do matrimônio oficializado pela Igreja Católica, em comparação com outras regiões e períodos. Por outro lado, também são realizados estudos de caso, de modo a atentar para o envolvimento — direto ou indireto - das elites no compadrio com os cativos: tais momentos podiam servir, por exemplo, para ampliar a rede de relações dos maiores potentados com livres subalternos — que, por sua vez, buscavam ascender socialmente.

Palavras-chave: Compadrio - escravidão - elites e hierarquias sociais.

\section{Abstract}

This article looks into the peculiarities of slavery during the period of its consolidation in the main sugar producing area of Portuguese Brazil, by examining godparenthood practices and patterns in four rural parishes in Bahia from 1613 to 1700. By means of a quantitative analysis, the limited demographic relevance of the free people of color, the status of pardos and mulattoes in captivity and the rarity of Catholic marriage are shown, other regions and periods providing bases for comparison. On the other hand, a few case studies are also used to call attention to the participation of the elites in the spiritual kinship with slaves, be it direct or indirect. Such actions could be useful, for instance, to enlarge the network of social relationships of the great magnates with subaltern free people - who, in their turn, attempted to move upward in the social hierarchy.

Keywords: Godparenthood - slavery - elites and social hierarchies. 